\title{
An Adoption of Selected Ecological Agricultural Practices by the Farmers
}

\author{
Rahul Katiyar*, Arun Kumar Pal and Brij Mohan \\ Department of Agricultural Extension, Chandra Shekhar Azad University of Agriculture and \\ Technology, Kanpur, Uttar Pradesh -208002, India \\ *Corresponding author
}

\section{A B S T R A C T}

The main purpose of the study was to determine the adoption of selected ecological agricultural practices by the farmers and the factors influencing the adoption in district Kanpur Dehat. Two blocks were selected randomly from the district and three villages were selected on random basis from each block, thus a total of six villages were selected from two blocks, 20 respondents were randomly selected from each village thus a total of 120 respondents in total were interviewed on a structural schedule. The majority (70 per

\section{Keywords}

Ecological nutrient management, Ecological pest management.

Article Info

Accepted:

10 September 2017 Available Online: 10 October 2017 cent) of the farmers were middle-aged, higher proportion (74 per cent) of the farmers had cropping intensity above national average, the majority ( 65 per cent) of the farmers of the study area had low GO contact, highest proportion (53 per cent) of the farmer has medium favorable attitude towards ecological agriculture. Majority ( 86 per cent) of the farmers had very low to low composite adoption of selected ecological agricultural practices, ecological nutrient management practices ( 84 per cent) and ecological pest management practices (79 per cent), while none had high adoption of composite ecological agricultural practices, ecological nutrient management practices and ecological pest management practices. Among ecological nutrient management practices, adoption of cow dung ranked first followed by farm yard manure, Compost, Crop residue/weed fertilizer, Green manure and others. Among ecological pest management practices, adoption of proper weeding and eradication of insect/disease attacked plants/plant parts ranked first followed by Crop rotation, Use of quality seed, Pest resistant varieties and others. An overwhelming majority (83 per cent) of the respondent farmers had low to medium training exposure; these facts implied that extension educational programs including training need to be arranged by the concerned agencies for the farmers in order to achieve desired benefit in respect of ecological nutrient management practices.

\section{Introduction}

Until about four decades ago, crop yield in agricultural systems dependent on internal resources, recycling of organic matter, built-in biological control mechanisms and rainfall patterns. Agricultural yield were modest, but stable. Production was safeguarded by growing more than one crop or variety in space and time in a field as insurance against pest outbreaks or severe weather.
Inputs of nitrogen were gained by rotating major field crops with legumes. In turn rotations suppressed insects, weeds and diseases by effectively breaking the life cycles of these pests. But as agricultural modernization progressed, the ecologyfarming linkage was often broken as ecological principles were ignored and/or overridden. A growing number of people have 
become concerned about the long-term sustainability of existing food production systems. Today lack of rotations and diversification take away key self-regulating mechanisms, turning monocultures into highly vulnerable agro ecosystems dependent on high chemical inputs. However excessive reliance on monoculture farming and agro industrial inputs, such as capital-intensive technology, pesticides, and chemical fertilizers, has negatively impacted the environment and rural society. Nowadays "ecological diseases" have been grouped into two categories: diseases of the ecotype, which include erosion, loss of soil fertility, depletion of nutrient reserves, Salinization and alkalization, pollution of water systems, loss of fertile croplands to urban development, and diseases of the biocoenosis, which include loss of crop, wild plant, and animal genetic resources, elimination of natural enemies, pest resurgence and genetic resistance to pesticides, chemical contamination, and destruction of natural control mechanisms.

Under conditions of intensive management, treatment of such "diseases" requires an increase in the external costs to the extent that, in some agricultural systems, the amount of energy invested to produce a desired yield surpasses the energy harvested. Modern agricultural practices negatively affect pest natural enemies, which in turn do not find the necessary environmental resources and opportunities in monocultures to effectively and biologically suppress pests. Fertilizers, on the other hand, have been praised as being highly associated with the temporary increase in food production observed in many countries. National average rates of nitrate applied to most arable lands fluctuate between $120-550 \mathrm{~kg} \mathrm{~N} / \mathrm{ha}$. But the bountiful harvests created at least in part through the use of chemical fertilizers, have associated, and often hidden, costs. A primary reason why chemical fertilizers pollute the environment is due to wasteful application and the fact that crops use them inefficiently. The fertilizer that is not recovered by the crop ends up in the environment, mostly in surface water or in ground water. High nitrate levels are hazardous to human health and studies have linked nitrate uptake to methaemoglobinemia in children and to gastric, bladder and oesophageal cancers in adults. Chemical fertilizers can also become air pollutants, and have recently been implicated in the destruction of the ozone layer and in global warming. Their excessive use has also been linked to the acidification/salinization of soils and to a higher incidence of insect pests and diseases through mediation of negative nutritional changes in crop plants. It is clear then that the first wave of environmental problems is deeply rooted in the prevalent socioeconomic system which promotes monocultures and the use of high input technologies and agricultural practices that lead to natural resource degradation. Second wave of environmental problems indicates that as long as transgenic crops follow closely the pesticide paradigm, biotechnological products will do nothing but reinforce the pesticide treadmill in agro ecosystems, thus legitimizing the concerns that many scientists have expressed regarding the possible environmental risks of genetically engineered organisms.

\section{Materials and Methods}

The present study was conducted in Kanpur District of Uttar Pradesh. District Kanpur Dehat was purposively selected because this district is directly benefited by Chandra Shekhar Azad University Agriculture and Technology, Kanpur (UP). Another reason for selecting Kanpur as locale of the study was the background, as there were hardly a few studies of this kind conducted in Uttar Pradesh which could work as guidance for workers, planners and administrators of planning and implementation of Information Technologies in respect to farm technologies 
and their activities. Second stage of sampling technique includes selection of development blocks of district Kanpur dehat. Among 10 development blocks of district Kanpur dehat two blocks namely- Bhognippur and Rajpur selected randomly for the study purpose. Three villages were selected on random basis from each block, thus a total of six villages will be selected from two blocks including Dohrapur, Madanpur, Sahjanpur, Kandhi, Auredi and Jainpur. 20 respondents were randomly selected from each village thus a total of 120 respondents selected for the study area.

\section{Results and Discussion}

\section{Ecological nutrient management (Nutrient Management without Chemical fertilizers)}

It is evident from the Table 1 that a great majority ( 84 per cent) of the farmers belonged to very low to low adoption category of ecological nutrient management practices. Nobody belonged to high adoption category of ecological nutrient management practices. These facts implied that extension educational programs including training need to be arranged by the concerned agencies for the farmers in order to achieve desired benefit in respect of ecological nutrient management practices.

\section{Extent of adoption of ecological pest management practices}

Findings indicated that adoption of ecological pest management practices scores of the farmers ranged from 69.5 to 439 against the possible range of 0 to 1000 . The mean, standard deviation and co-efficient of variation were $271.60,68.83$ and $25.34 \%$ respectively. The farmers were classified into three categories on the basis of their adoption of ecological pest management practices as shown in Table 2.
Majority (74 per cent) of the farmers belonged to low adoption category as compared to 5 and 21 per cent belonged to very low and medium adoption category of ecological pest management practices, respectively. Thus, a great majority (79 per cent) of the farmers belonged to very low to low adoption category of ecological pest management practices. Nobody belonged to high adoption category of ecological pest management practices. These facts implied that training and non-formal educational programs need to be organized by the concerned agencies for the farmers in order to achieve desired benefit in respect of ecological pest management practices.

$\mathrm{ANM}=$ Adoption of ecological nutrient management practices

APM $=$ Adoption of ecological pest management practices

$\mathrm{CA}=$ Composite adoption of selected ecological agricultural practices

Foregoing discussion indicated a gloomy situation as far as the extent of adoption of ecological nutrient management practices, ecological pest management practices and composite adoption of ecological agricultural practices were concerned. This implied that more and more motivational programs including training and non-formal educational programs need to be arranged by the concerned agencies for the farmers in order to achieve desired benefit with regard to selected ecological agricultural practices.

\section{Comparative extent of adoption of selected ecological agricultural practices}

Attempt has been made in this selection of compare the extent of adoption of different ecological agricultural practices with the help of Adoption Index (AI). Adoption index for 
each for the practices was determined by using the following formula.

$\mathrm{AI}=\mathrm{A}_{\mathrm{n}} \times 0+\mathrm{A}_{1} \times 1+\mathrm{A}_{\mathrm{m}} \times 2+\mathrm{A}_{\mathrm{h}} \times 3$

Where,

$\mathrm{AI}=$ Adoption Index
$A_{n}=$ Per cent of farmers having no adoption

$\mathrm{A}_{1}=$ Per cent of farmers having low adoption

$\mathrm{A}_{\mathrm{m}}=$ Per cent of farmers having medium adoption

$A_{h}=$ Per cent of farmers having high adoption

Table.1 Salient features and distribution of the farmers according to their extent of adoption of ecological nutrient management practices

\begin{tabular}{|c|c|c|c|c|c|c|c|c|}
\hline $\begin{array}{l}\text { Dimensions of } \\
\text { Eco-agril. } \\
\text { Practices }\end{array}$ & Categories & \multicolumn{2}{|c|}{ Range } & \multicolumn{2}{|c|}{ Farmers } & Mean & SD & $\begin{array}{l}\text { CV } \\
\%\end{array}$ \\
\hline \multirow{5}{*}{$\begin{array}{l}\text { Ecological } \\
\text { Nutrient } \\
\text { management } \\
\text { practices }\end{array}$} & Adoption & Possible & Observed & Number & Per cent & & & \\
\hline & $\begin{array}{l}\text { Very low } \\
\text { (up to } 166.7 \text { ) }\end{array}$ & \multirow[t]{3}{*}{ 0-1000 } & \multirow[t]{3}{*}{ 88.3-470 } & 20 & 17 & \multirow[t]{4}{*}{242.11} & \multirow[t]{4}{*}{78.17} & \multirow[t]{4}{*}{32.29} \\
\hline & $\begin{array}{l}\text { Low } \\
(166.8- \\
333.3)\end{array}$ & & & 81 & 67 & & & \\
\hline & $\begin{array}{l}\text { Medium } \\
\text { (above } \\
333.3 \text { ) } \\
\end{array}$ & & & 19 & 16 & & & \\
\hline & Total & & & 120 & 100 & & & \\
\hline
\end{tabular}

Table.2 Salient features and distribution of the farmers according to their extent of adoption ecological pest management practices

\begin{tabular}{|c|c|c|c|c|c|c|c|c|}
\hline $\begin{array}{l}\text { Dimensions of } \\
\text { Eco-agril. } \\
\text { Practices } \\
\end{array}$ & Categories & & nge & Far & ners & \multirow[t]{2}{*}{ Mean } & \multirow[t]{2}{*}{ SD } & \multirow{2}{*}{$\begin{array}{l}\mathbf{C V} \\
\%\end{array}$} \\
\hline \multirow{5}{*}{$\begin{array}{l}\text { Ecological } \\
\text { pest } \\
\text { management } \\
\text { practices }\end{array}$} & Adoption & Possible & Observed & Number & Per cent & & & \\
\hline & $\begin{array}{l}\text { Very low } \\
\text { (upto } 166.7 \text { ) }\end{array}$ & \multirow[t]{3}{*}{ 0-1000 } & \multirow[t]{3}{*}{ 39.5-439 } & 6 & 5 & \multirow[t]{4}{*}{271.60} & \multirow[t]{4}{*}{68.83} & \multirow[t]{4}{*}{25.34} \\
\hline & $\begin{array}{l}\text { Low } \\
(166.8- \\
333.3)\end{array}$ & & & 89 & 74 & & & \\
\hline & $\begin{array}{l}\text { Medium } \\
\text { (above } \\
333.3 \text { ) }\end{array}$ & & & 25 & 21 & & & \\
\hline & Total & & & 120 & 100 & & & \\
\hline
\end{tabular}


Table.3 Comparative adoption of ecological nutrient management practices

\begin{tabular}{|c|c|c|c|c|c|c|}
\hline \multirow[t]{2}{*}{ Practices } & \multicolumn{4}{|c|}{ \% of farmers having } & \multirow{2}{*}{$\begin{array}{l}\text { Adoption } \\
\text { Index (AI) }\end{array}$} & \multirow{2}{*}{$\begin{array}{l}\text { Rank } \\
\text { Order }\end{array}$} \\
\hline & $\begin{array}{c}\text { No } \\
\text { adoption } \\
\left(\mathbf{A}_{n}\right)\end{array}$ & $\begin{array}{c}\text { Low } \\
\text { adoption } \\
\left(\mathbf{A}_{1}\right)\end{array}$ & $\begin{array}{c}\text { Medium } \\
\text { adoption } \\
\left(\mathbf{A}_{\mathrm{m}}\right)\end{array}$ & $\begin{array}{c}\text { High } \\
\text { adoption } \\
\left(\mathbf{A}_{\mathbf{h}}\right)\end{array}$ & & \\
\hline 1. Cowdung & 2 & 18 & 42 & 38 & 216 & 1 \\
\hline 2. Poultry excreta & 98 & 2 & 0 & 0 & 2 & 8 \\
\hline 3. Farm yard manure & 4 & 20 & 46 & 30 & 202 & 2 \\
\hline 4. Compost & 10 & 12 & 46 & 32 & 200 & 3 \\
\hline 5. Quick compost/Oil cake & 95 & 2 & 3 & 0 & 8 & 6 \\
\hline 6. Liquid organic fertilizes & 99 & 1 & 0 & 0 & 1 & 9 \\
\hline 7. Water hyacinth & 99 & 1 & 0 & 0 & 1 & 9 \\
\hline 8. Green manure & 47 & 48 & 5 & 0 & 58 & 5 \\
\hline $\begin{array}{ll}\text { 9.Crop } & \text { residue/weed } \\
\text { fertilizer } & \end{array}$ & 42 & 32 & 21 & 5 & 89 & 4 \\
\hline 10. Biofertilizers & 95 & 3 & 2 & 0 & 7 & 7 \\
\hline
\end{tabular}

Table.4 Comparative adoption of ecological pest management practices

\begin{tabular}{|c|c|c|c|c|c|c|}
\hline \multirow[t]{2}{*}{ Practices } & \multicolumn{4}{|c|}{$\%$ of farmers having } & \multirow{2}{*}{$\begin{array}{l}\text { Adoption } \\
\text { Index } \\
\text { (AI) }\end{array}$} & \multirow{2}{*}{$\begin{array}{l}\text { Rank } \\
\text { Order }\end{array}$} \\
\hline & $\begin{array}{c}\text { No } \\
\text { adoption } \\
\left(\mathbf{A}_{n}\right)\end{array}$ & $\begin{array}{c}\text { Low } \\
\text { adoption } \\
\left(\mathbf{A}_{1}\right)\end{array}$ & $\begin{array}{l}\text { Medium } \\
\text { adoption } \\
\left(\mathbf{A}_{\mathrm{m}}\right)\end{array}$ & $\begin{array}{c}\text { High } \\
\text { adoption } \\
\left(\mathrm{A}_{\mathrm{h}}\right)\end{array}$ & & \\
\hline 1. Pest control by hand/hand net & 100 & 0 & 0 & 0 & 0 & 10 \\
\hline $\begin{array}{l}\text { 2. Putting tree branches in the } \\
\text { field }\end{array}$ & 90 & 4 & 1 & 0 & 6 & 7 \\
\hline 3. Light trap & 80 & 8 & 2 & 0 & 12 & 5 \\
\hline $\begin{array}{l}\text { 4. Bot. pesticides (neem, nishinda, } \\
\text { biskatali, garlic, extract etc.) }\end{array}$ & 70 & 20 & 9 & 1 & 41 & 4 \\
\hline 5. Use of quality seed & 30 & 50 & 15 & 5 & 95 & 3 \\
\hline 6. Pest control by ash & 98 & 2 & 0 & 0 & 2 & 8 \\
\hline 7. Beneficial insects & 99 & 1 & 0 & 0 & 1 & 9 \\
\hline 8. Pest resistant varieties & 90 & 9 & 1 & 0 & 11 & 6 \\
\hline 9. Crop rotation & 1 & 36 & 53 & 10 & 172 & 2 \\
\hline $\begin{array}{l}\text { 10. Proper weeding and } \\
\text { eradication of insect/disease } \\
\text { attacked plants/plant parts }\end{array}$ & 5 & 3 & 29 & 63 & 240 & 1 \\
\hline
\end{tabular}

The possible range of adoption scores of each ecological agricultural practice was 0 to 100 . Based on this consideration, adoption score of 0 , up to $33.3,33.4$ to 66.7 , and above 66.7 were considered as no, low, medium and high adoption respectively for each practice.
Thus, the possible range of adoption indices (AIs) of the practices could range from 0 to 300 , where 0 indicated no adoption and 300 indicated highest adoption. In order to have a comparative understanding, based on descending order to adoption index (AI), risk 
order was made among ecological nutrient management practices and ecological pest management practices separately as shown in Tables 3 and 4.

\section{Comparative adoption of ten ecological nutrient management practices}

Among ten ecological nutrient management practices, adoption of cow dung ranked first followed by crop residue/weed fertilizer, compost, poultry excreta, farm yard manure, water hyacinth, quick compost/oil cake, green manure, and liquid organic fertilizers.

Nobody used bio-fertilizers in their pulses crop fields.

Among ten ecological pest management practices, adoption of proper weeding and eradication of insect/disease attacked plants/plant parts ranked first followed by use of quality seed, crop rotation, pest control by ash, pest control by hand/hand net, putting tree branches in the field, botanical pesticides (neem: Azadirachta indica, Nishinda: Vitex negundo, biskatali: Polygonum orientale, garlie: Allium sativum extract etc.), beneficial insects and light trap.

Nobody used pest resistant varieties in their crop fields.

Majority (86 percent) of the farmers had very low to low composite adoption of selected ecological agricultural practices, ecological nutrient management practices (84 percent) and ecological pest management practices (79 percent), while none had high adoption of ecological nutrient management practices and ecological pest management practices. Among ecological nutrient management practices, adoption of cow dung ranked first followed by farm yard manure, Compost, Crop residue/weed fertilizer, Green manure and others. Among ecological pest management practices, adoption of proper weeding and eradication of insect/disease attacked plants/plant parts ranked first followed by Crop rotation, Use of quality seed, Pest resistant varieties and others.

Therefore, it may be concluded that necessary motivational programmes need to be taken by the concerned authorities so that the farmers could increase their land under ecological agricultural practices gradually. Unlike chemical fertilizers, organic fertilizers usually have low content of plant nutrient. This goes against the use of organic fertilizers. Therefore, research should be conducted to explore organic fertilizers having high content of NPK and other nutrient.

\section{References}

Albritton, R., 2009. Let them eat junk: how capitalism creates hunger and obesity. Pluto Press: 272.

Alexandratos, N., 2005. Countries with rapid population growth and resource constraints: issues of food, agriculture, and development. Popul. Dev. Rev. 31, 237. Losey, J. E. and Vaughan, M. (2006). "The economic value of ecological services provided by insects". Bioscience 56, 311-323.

Baccini, A., Goetz, S. J., Walker, W. S., Laporte, N. T., Sun, M. and SullaMenashe, D. et al., (2012). Estimated carbon dioxide emissions from tropical deforestation improved by carbondensity maps. Nature Clim. Change, 2, 182-185

Baumgartner, H., 2000. Swiss Agriculture on its Way to Sustainability. Bern: BBL/EDMZ,

SchweizBundesamtfürUmwelt, Warld und Lands-haft.

Beddington, J., Asaduzzaman, M., Fernandez, A., Clark, M., Guillou, M. and Jahn, M. et al., 2011. Achieving food security in the face of climate change: summary for 
policy makers from the commission on sustainable agriculture and climate change in CGIAR. Agriculture and Food Security.

Bellon, S., Lamine, C., Ollivier, G. and Abreu, D. L. 2009. The Relationships between Organic Farming and Agroecology. Ecol. Econ. 41, 95-107.

Berkes, F., Colding, J. and Folke, C. 2000, Rediscovery of traditional ecological knowledge as adaptive management. Ecological Applications, 10: 12511262.

Bloom, B.S., 1956. Taxonomy of Educational Objectives, Handbook 1: The Cognitive Domain, New York: David Mckay Co. Inc.

Chappell, M. J., and Lavalle, L. A. 2011. Food security and biodiversity: can we have both an agroecological analysis. Agric. Hum. Values, 28, 3-26.

Crowder, D. W., and Reganold, J. P. 2015. Financial competitiveness of organic agriculture on a global scale. Proc. Natl. Acad. Sci. U.S.A. 112, 7611-7616.

FAO. 2006. Papers submitted for International Conference on Organic Agriculture and Food Security.

Ferguson, et al., Agron. Sustain. Dev. 2014. Agro ecology is a promising alternative to industrial agriculture, with the potential to avoid the negative social and ecological consequences of inputintensive production. 34: 251.

Forster, D., Andres, C., Verma, R., Zundel, C., Messmer, M. M. and Mäder, P. 2013b. Yield and economic performance of organic and conventional cotton-based farming systems - results from a field trial in India. PLoS ONE 8: 81039.

Halberg, N., Sulser, T. B., Hogh-Jensen, H., Rosengrant, M. W., and Knudsen, M. T. 2006. The impact of organic farming on food security in a regional and global perspective. In N. Halberg, H. F. Alroe,
M. T. Knudsen, and E. S. Kristensen (Eds.), Global Development of Organic Agriculture: Challenges and Prospsects(pp. 277 - 322). Wallingford, UK: CABI Publishing.

Hart, B., 1994. Sanrem, inforam Electronic Conference on Indicators of Sustainability. Erasmus Pennsylvania: Rodale Press.

Hassanali, A., Herren, H., Khan, Z., Pickett, J., and Woodcock, C. 2008. Integrated pest management: the push-pull approach for controlling insect pests and weeds of cereals, and its potential for other agricultural systems including animal husbandry. Philosophical Transactions of the Royal Society B: Biological Sciences, 363, 611-621.

Joshi, M., and T.K. Prabhakarasetting 2005. Sustainability through Organic Farming, India: Kalyani Publishers.

Kassam, A.H., Friedrich, T., Shaxon, F., Reeves, T., Pretty, J. and De MoraesSá, J.C. 2011. Production systems for sustainable intensification, integrating productivity with ecosystem services. Theorie und Praxis, 20 (2): 38-45.

Lal, R., Singh, B. R., Mwaseba, D. L., Kraybill, D., Hansen, D. O. and Eik, L. O. 2015. Sustainable Intensification to Advance Food Security and Enhance Climate Resilience in Africa. Cham: Springer International Publishing.

Lee, D. R., 2005. Agricultural sustainability and technology adoption: issues and policies for developing countries. American Journal of Agricultural Economics, (87)5, 1325-1334.

Niggli, U., Baker, B., Rahmann, G., Ssebunya, B., Cuoco, E. and Wivstad, M. 2014. A Global Vision and Strategy for Organic Farming. Agrofor. Syst. 71, 139-149.

Parrott, N., Olesen, J. E., and Hogh-Jensen, H. 2006. Certified and non-certified organic farming in the developing 
world. In N. Halberg, H. F. Alroe, M. T. Knudsen, and E. S. Kristensen (Eds.). Global Development of Organic Agriculture: Challenges and Prospsects (pp. 154-179). Wallingford, UK: CABI Publishing.

Pender, J., and Mertz, O. 2006. Soil fertility depletion in sub-Saharan Africa: what is the role of organic agriculture? In $\mathrm{N}$. Halberg, H. F. Alroe, M. T. Knudsen, and E. S. Kristensen (Eds.), Global Development of Organic Agriculture: Challenges and Prospsects(pp. 215240). Wallingford, UK: CABI Publishing. imentel, D., 1996. Green revolution agriculture and chemical hazards. Sci. Total Environ. 188 (96): S86-S98.

Pretty, J., 2008. Agricultural sustainability: concepts, principles and evidence. Philosophical Transactions of the Royal Society B: Biological Sciences, 363, 447-465.

Pretty, J., et al., 2006. Resource-conserving agriculture increases yields in developing countries. Environmental Science and Technology, 40(4), 11141119.

Pretty, J., Morison, J., and Hine, R. 2003. Reducing food poverty by increasing agricultural sustainability in developing countries. Agriculture, Ecosystems and Environment, 95, 217-234.

Rosset, P.M., Sosa, B.M., Jaime, A.M.R. and Lozano, D.R.A. 2011. The Campesinoto-Campesinoagroecology movement of
ANAP in Cuba: social process methodology in the construction of sustainable agriculture and food sovereignty. The Journal of Peasant Studies, 38 (1): 161-191.

SCAR, 2011. Sustainable food consumption and production in a resourceconstrained world, in European Commission - Standing Committee on Agricultural Research, Brussels, 150.

Scialabba, N.E.H., and Williamson, D. 2004. The scope of organic agriculture, sustainable forest management and ecoforestry in protected area management. FAO, Rome, Italy.

Shiferaw, B. A., Okello, J., and Reddy, R. V. 2009. Adoption and adaptation of natural resource management innovations in smallholder agriculture: reflections on key lessons and best practices. Environment, Development and Sustainability, 11(3), 601-619.

Sims, B., Friedrich, T., Kassam, A. and Kienzle, J. 2009. Agroforestry and Conservation Agriculture: Complementary practices for sustainable development. Agriculture for Development, 8: 13-20.

Willer, H., and Lernoud, J. 2015. The World of Organic Agriculture - Statistics and Emerging Trends. Research Institute of Organic Agriculture (FiBL), Frick, and IFOAM Organic International.

Zhengfang, I., 1995. Ecological Agriculture China. The Journal of Rural Development. BARD, 25(1): 1-24.

\section{How to cite this article:}

Rahul Katiyar, Arun Kumar Pal and Brij Mohan. 2017. An Adoption of Selected Ecological Agricultural Practices by the Farmers. Int.J.Curr.Microbiol.App.Sci. 6(10): 1004-1011. doi: https://doi.org/10.20546/ijcmas.2017.610.121 